\title{
The Characteristics of Ultimate Controller and Entrepreneurial Orientation: Theoretical analysis of Chinese Context
}

\author{
Yang YANG $^{1, a,{ }^{*}}$, Xiao- Feng JU ${ }^{1, b}$ \\ ${ }^{1}$ School of Management, Harbin Institute of Technology, China \\ akobeyang827@163.com, buxf@hit.edu.cn
}

\begin{abstract}
Keywords: Ultimate controller, Nature of firms, Separation of control rights and Ownership, Entrepreneurial orientation.
\end{abstract}

\begin{abstract}
Comparing with consequences of entrepreneurial orientation, fewer literature focused on antecedents of entrepreneurial orientation. In addition, the antecedents of entrepreneurial orientation were mainly examined in American context and fewer studies concentrated on Chinese context. In this paper, we conducted a theoretical analysis of relationship between characteristics of ultimate controller and entrepreneurial orientation in Chinese contexts. Most listed Chinese firms exist a dominant ultimate controller. The controllers may be state-owned and non-state-owned. Also, they format separation of control rights and ownership by pyramid and cross shareholding. Comparing with managers, they has predominant influences on firm's strategic decisions. Using three theories, that is , institutional theory, upper echelons theory and agency theory, we discuss the relationship between characteristics of ultimate controller and entrepreneurial orientation. At last, we argue that market development may moderate relationship between characteristics of ultimate controller and entrepreneurial orientation.
\end{abstract}

\section{Introduction}

In highly dynamic and fiercely competitive environment, strategy-making becomes increasingly important to firms' survival and growth. As a firm strategy, entrepreneurial orientation(thereafter EO) is a concept to capture the firms' behavioral characteristics in product innovation, opportunity exploitation and exploration and resource allocation process. Scholars argue that firms with high EO are more likely to encourage creative ideas and novel experiments in product innovation, are tend to make resource commitment to projects or innovative behaviors that with costly

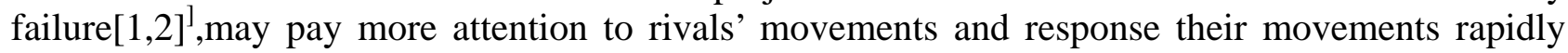
and frequently[3]. Also, high EO firms may have a looking-forward attitude to growth opportunities, they prefer exploring new opportunities to merely deeply exploiting current ones[4].

Along with the strategy-making framework, prior literature about EO can be divided into two categories. The first group is consequences of $\mathrm{EO}$, they aim to investigate the direct and indirect relationships between EO and firms' financial performance, growth opportunities and firm-value creation. At last, the contingency framework of relationship between EO and firm performance is build [3]. Along with this framework, a majority of mediating and moderating variables have been identified and further examined in empirical studies. The other group focuses on antecedents of EO, a research topic that has been discussed much less. What's more, most previous studies have been conducted in American or European contexts, rather than emerging market and developing countries context[5].In fact, China is a attractive context for scholars to examine potential antecedents of EO.

\section{Literature Review about Antecedents of Entrepreneurial Orientation}

Previous studies about antecedents of EO were mainly concentrate on firms' internal factors, external environment and characteristics of firms' stakeholders[6].The internal factors are corporate governance[7],organizational culture, new knowledge creation and organizations' innovation abilities. Some studies focuses on external environment. They argue that institutional, social, economic and cultural factors like government intervention, regional inventor protection, development of regional and national financing[8],uncertainty and dynamic of industrial 
environment have great influence on EO. Also, other studies think that EO would be affected by diversity of stakeholder, CEO's overconfident, tenure, age, shareholding and heterogeneity of top management team $[9,10]$.

However, previous studies mainly capture generality and ignore the national and regional institutional differences. Most prior antecedents of EO are grounded in American context and these studies keep silent in potential antecedents in Chinese context. What's more, most studies about institutional differences are concentrate on national differences, fewer studies focus on regional differences. China is a perfect context to investigate regional institutional differences, for its unbalanced level of economy and market development. Besides, in terms of theories, institution theory and upper echelons theory have been applied by a majority of scholars to identify and investigate antecedents of EO. Most of these studies naturally agree with the argument that all firms' stakeholders would make decisions that aligning with the whole firms' interests. In fact, agency theory argue that the strategic decisions may be affected by interests conflicts among stakeholders. This situation would be more distinct when top manager team or majority shareholder have determinant influence in firms' strategic decisions. Because they are able to make strategic decisions that are optimal for their personal interests, but sub-optimal for interests of the whole firm or other stakeholder.

\section{Institutional Background of China}

\section{Institutional Background}

Unlike American context, Chinese public firms still overwhelmingly rely on bank loans to satisfy their need for capital[11].Although bond markets, venture capital and angel capital have been growing rapidly, they remain undeveloped presently. Credit rationing of bank loans may aggravate financing dilemma in small and medium enterprises which without political connection and are unable to provide mortgage assets[5].In addition, unbalanced developing levels is existed in China[12]. These regional developing differences are displayed by government intervention, marketization, development of intermediary institutions and financing market. From area perspective, southeast and middle area of China have distinctly higher developed marketization, financing market and intermediary institutions than northeast and northwest areas. From cities perspective, Beijing and Tianjin, Shanghai which is center city of Yangtze River Delta Region, Guangzhou and Shenzhen which are center cities of Pearl River Delta Region have distinctly higher developed marketization, financing market and intermediary institutions than other cities in China. Therefore, China provides scholars with an attractive context to further investigate how institutional environment influence EO[13,14].

\section{Characteristics of Public Firms}

Firstly, unlike American public firms which characterized by diverse ownership structure, Most Chinese listed firms have a highly concentrated ownership structure and a dominant ultimate controller. Researches from Shanghai Securities(Joint) Group shows that $84.57 \%$ Chinese listed firms have a shareholder that can absolutely or relatively control rights the whole firm. It means most listed firms have a dominant ultimate controller and the controller may have predominant influence in firm's financial decisions, choosing board of directors members and firm's top management team[15].Secondly, the characteristics of ultimate controller are various. The differences can be captured by two aspects, nature of ultimate controller and the degree of separation of control rights and ownership. According to nature, ultimate controller can be divided into two groups, state-owned enterprises(SOE)and non-state-owned enterprises(NSOE).China is under a dramatic transition from planned economy to market orientated economy and its economy pattern is characterized with public sectors remaining dominant and diverse sectors developing side by side. On one hand, the governments participant in market competition by SOE, on the other hand, they rely on SOE and financial institutions to regulate national economy. Comparing with NSOE, SOE has more diverse operating goals, despite of financial performance, it also take responsibility 
for social goals. In order to achieve these goals, government should provide SOE with implicit guarantee and give it soft budget constraints. So, SOE is more likely to gain bank loans, especially credit loans with lower cost. In terms of separation of control rights and ownership, the ultimate controller uses pyramid and cross shareholding to format differences between control rights and ownership. With this separation, ultimate controller can control the whole firm resources with relatively smaller ownership. To sum up, with undeveloped financing market, unbalanced economy development, most listed Chinese firms exist a dominant ultimate controller. The characteristics of controller are as follows: (1)according to nature, it can be divided into SOE and NSOE; (2)separation of control rights and ownership is formatted by controller's pyramid and cross shareholding; (3)comparing with managers, the ultimate controller has predominant influence on firm's strategic decisions.

\section{The Characteristics of Ultimate Controller and Entrepreneurial Orientation: Theoretical Analysis}

\section{Institutional Theory}

Institutional theory emphasizes the influences of the characteristics of context and systems that shape firms' strategic postures and it has been utilized to explain firms' strategic decisions[16].In Chinese context, we argue that EO may be influenced by ultimate controller's characteristics. To begin with, Chinese listed firms have a concentrated ownership structure which is not the same with American firms. Most listed firms have a dominant ultimate controller. In addition, the nature of ultimate controller can be divided into SOE and NSOE. Comparing with NSOE, SOE has advantages in gaining resources with a lower cost. With this resources endowment advantage, SOE is more capable to conduct EO, a resource-consuming strategy. Also, SOE was born in planned economy. It may have a disadvantage over NSOE in experiences in product innovation and marketing-oriented competition. What's more, SOE has more diversified goals. Despite of financial performance, it may burden social responsibilities. These additional goals may prohibit SOE from allocating resources in $\mathrm{EO}$ which is a risk-taking and innovative activities. At last, the ultimate controller can control rights firm's whole resources with relatively lower ownership by pyramid and cross shareholding. The separation between ownership and control rights, on one hand, can mitigate financial constraint dilemma, therefore encouraging listed firms to conduct EO. On the other hand, the separation may also make contribution to ultimate controllers' opportunist behaviors that do harm to firms' value creation. To sum up, the nature and separation of ownership and control rights can be regarded as endogenous variables of Chinese institutional context, which is characterized by undeveloped financial market and unbalanced regional economic development. And these variables may further influence public firms’ choices of EO strategy.

\section{Upper Echelons Theory}

Upper echelons theory argues that the individual and team characteristics of top managers may influence firms' strategic postures. These characteristics are top management teams' professional and education background, age, CEO overconfident. This theory implicitly agrees that top management team or managers may have predominant influences in firms' strategic decisions. However, this assumption may be merely suitable to the diversified ownership structure context. In Chinese listed firms, the people who have predominant influences to firms' strategic decisions are ultimate controller, rather than top managers. So, upper echelons theory should be extended and modified when it is applied to Chinese context. Despite of top management team characteristics, more stakeholders' characteristics should be considered. These stakeholders are ultimate controller, majority and minority shareholder, institutional investors, suppliers and customers. Firms' strategic decisions results from negotiation and bargains among all the stakeholders. Ultimate controller may be the most powerful stakeholder in listed firms in China. Therefore, the nature and separation of ownership of ultimate controller may be more essential antecedents of EO than top management team characteristics. 


\section{Agency Theory}

Agency theory emphasizes that with information asymmetry the conflicts between stakeholders may influence their behaviors, eventually influence firms' strategic choices. The interests conflicts between stockholder and managers, stockholder(managers) and lenders, majority and minority shareholders have been examined in prior studies. In a diversified ownership context, agency problems can be described as interests conflicts between shareholder and managers which caused by separation of ownership and operation rights. In this situation, managers have operational rights to determine firms' strategy and they are motivated to pursue empire building, Exclusive and non-pecuniary consumption[17].In China, agency problems are twofold, on one hand, interests conflicts between managers and shareholders, on the other hand, interests conflicts between majority and minority shareholders. Further, the predominant agency problems are determined by characteristics of ultimate controllers. In NSOE, the dominant agency problems are caused by ultimate controllers' separation of ownership and control rights. With this separation, ultimate controller may be motivated to conduct tunneling behaviors $[18,19]$ which do harm to interests of minority shareholder. However, the ultimate controller of SEO is government or its subsidiary institution and these institutions are nominal controllers. The managers of SEO are the actual agent and they have predominant influence in SEO's operational decisions. So, the interests conflicts are existing between managers and shareholder. What's more, unlike the situation of separation of ownership and operational rights, the managers of SOE are government officials, rather than professional managers. Although many decisions rights are delegated to managers, the government retains the ultimate decisions rights in terms of disposal of assets and appointment of managers. Therefore, managers of SOE should trade-off between the benefit of opportunist behaviors and their promotion. With predominant rights to determine firms' strategy, both managers and ultimate controller may pursue self-interests at the expense of other stakeholder or firms' benefits. EO is a resource-consuming activity, it reflect firms' tendency to allocate valuable resources. According to the way of value creation, EO can be divided into two group, that is, research and development orientation and aggressive-asset growth orientation. Comparing with research and development orientation, aggressive-asset growth orientation prefer short-term performance and external resources growth. From looking-forward perspective, research and development orientation focuses on internal resources integration and may be more essential to firms' long-term performance and competitive advantage. Previous studies reveal that SEO is tend to over-investment and have strong tendency to pursue firm size, instead NSOE is constrained by under-investment. Also, when ultimate controller can control whole resources with relative low ownership, on one hand, the separation of ownership and control rights can provide ultimate controller with cover to misappropriate firms' resource when conducting EO, especially aggressive-assets growth activities. On the other hand, the separation of ownership and control rights may help resolve the financial constrain and under-investment problems, then encouraging ultimate controller to allocate resources to research and development orientation EO, which is aligning with the interests of firms' value creation.

The theories mentioned above provide theoretical cues for scholars to identify antecedents of EO from different perspectives and levels. Institutional theory belongs to macro level. It reveals that in Chinese institutional environment we can find some unique antecedents which are different from American context. In order to identify the antecedents accurately, we have to pay attention to characteristics of Chinese listed firms. Combing the institutional theory with unique firm characteristics, we can clarify that characteristics of ultimate controller are potential antecedents of EO. Unlike institutional theory, upper echelons and agency theories belong to micro level. Both of theses two theories agree that firms' strategic choices, like EO, can be influenced by stakeholders. However, each of these two theories clarify antecedents from two perspectives. Upper echelons theory argues that cognitive modes and psychological characteristics of top management teams or individual managers may have dominant influence in EO. But agency theory which is an emerging theory in EO and belongs to economy theory. It emphasizes interests conflicts between stakeholders which are neglected by upper echelons theory. In Chinese context, upper echelons theory should be 
extended and modified. Because in a context with concentrated ownership structure and a dominant ultimate controller, firms' EO decisions are determined by ultimate controller and other shareholders, rather than top managers. Therefore, instead of limited to top management team, the scope of the antecedents in upper echelons theory should be extended to ultimate controllers' characteristics. To sum up, both agency and upper echelons theories intend to explain why firm fail to make optimal decisions in EO, the former theory's response is interests conflicts, the other one's answer are cognitive modes and psychological characteristics of stakeholders.

\section{Moderating Effects of Regional Market Development}

We further discuss moderating effects of market development in relationship between characteristics of ultimate controller and EO. Chinese unbalanced regional market development provides scholar with an unique context to further investigate how institutional environment influence EO in different regions in one country. Prior studies mainly focus on differences between various nations. High market development has been found that it may constrain SOE's over investment, alleviate NSOE's under investment, limit opportunist behaviors of managers and ultimate controllers. Thus, we argue that with the increase of market development, strategic decisions, like EO, would be more market-oriented. That means SOE may allocate more resources to research development orientation and overcome aggressive-asset growth tendency. NSOE are capable to engage research development orientation and get rid of financial constrain in some degree. In terms of separation of ownership and control rights, the influence may be more complicated. Although both in high and low market development regions, firms' dominant EO orientation is R\&D type, the reasons are various. With low market development, the explanation of $\mathrm{R} \& \mathrm{D}$ orientation tendency is that separation can be regarded as a mechanism to solve financial constrain, then boosting firms' R\&D orientation, though at this time, ultimate controller that may have strongest motivation to conduct opportunist behaviors that do harm to firm's value creation. With high market development, the tendency can be attributed to enhancement of $R \& D$ and inhibition of aggressive-asset growth orientations. In this situation, the R\&D tendency is strongest.

\section{References}

[1] Covin JG, Slevin D., Strategic management of small firms in hostile and benign environments. Strategic Management Journal 10(1)(1989) 75-87.

[2] Miller D., The correlates of entrepreneurship in three types of firms. Management Science 29(7)(1983) 770-791.

[3] Lumpkin GT, Dess GG. ,Clarifying the EO construct and linking it to performance. Academy of Management Review(1996) 135-172.

[4] Lumpkin GT, Dess GG.,Linking two dimensions of EO to firm performance: The moderating role of environment and industry life cycle. Journal of Business Venturing 16(5)(2001).

[5] Tang J, Tang Z, Marino LD, Zhang Y, Li Q. Exploring an inverted U-shaped relationship between entrepreneurial orientation and performance in Chinese ventures. Entrepreneurship Theory and Practice 32(1)(2008) 219-239

[6] Wales William J., Gupta Vishal K. and Mousa Fariss T. Empirical research on

entrepreneurial orientation: An assessment and suggestions for future research[J]. International Small Business Journal 31(4)(2013) 357-383

[7]Liu Hongwei, Li Jun. The empirical study of corporate governance and entrepreneurial orientation[J]. Technological Economy 34(2)(2015) 27-34(In Chinese)

[8]Liu Wei, Yang Beibei and Liu Yanyan. Institutional environment and new ventures' entrepreneurial orientation: evidence from Growth Enterprise Market[J]. Studies in Science of 
Science 32(3)92014) 421-430(In Chinese)

[9]Yang Lin. Heterogeneity of top management team, nature of ownership and entrepreneurial orientation: evidence from Chinese listed firms of Small and Medium market[J].Science of Science and Management of S.\&T.(9)(2013)(In Chinese)

[10]Yang Lin. Vertical differences of top management team and entrepreneurial orientation: moderating effects of industrial environment and nature of ownership[J].Nan Kai Management Review(1)(2014)(In Chinese)

[11]Chen, H.W., Wang, Y.Y., Chen, J.Z., Lobo, G.J., Association between borrower and lender state ownership and accounting conservatism[J]. Journal of Accounting Research 48(2010) 973-1014

[12]Wang Q., T.J. Wong and L. Xia, State Ownership, the Institutional Environment, and Auditor Choice: Evidence from China [J], Journal of Accounting and Economics (46)(2008) 112-134

[13]Bruton Garry D., Ahlstrom D., Li. Institutional theory and entrepreneurship: where are we now and where do we need to move in the Future?[J]. Entrepreneurship Theory and Practice (May)(2010), 421-440

[14]Bruton Garry D., Ahlstrom D., Obloj K. Entrepreneurship in emerging economies:

where are we today and where should the research go in the future[J]. Entrepreneurship Theory and Practice 32(1)( 2008) 1-14

[15]Xiao Zuoping. The structure of ultimate controllers' ownership and firms' capital structure choices: evidence from Chinese listed firm[J].Chinese Management Science 20(4)(2012) 167-176(In Chinese)

[16]Scott, W.R. Institutions and organizations[M]. Thousand Oaks, CA: Sage Publications, 2009

[17]Jensen M.C., Meckling W.H. Theory of the firm: managerial behavior, agency costs, and capital structure[J]. Journal of Financial Economics (3)(1976) 305-360

[18]Claessens S., Djankov S., Lang L.H.P. The separation of ownership and control in east Asian corporations [J].Journal of Financial Economics (58) (2000) 81-112

[19]Johnson S., La Porta R., Lopez-de-Silanes F. and Shleifer A. Tunneling[J].The American Economic Review 90(2)(2000) 22-27 